\title{
MODIFIKASI PERMUKAAN SERAT LBKP DAN HASIL DEINKING DENGAN KARBOKSIMETIL SELULOSA
}

\author{
Sonny Kurnia Wirawan *, Nina Elyani, Jenni Rismijana \\ Balai Besar Pulp dan Kertas, Jl. Raya Dayeuhkolot 132 Bandung \\ *sonny_bbpk@yahoo.co.id \\ Diterima : 06 Nopember 2012, Revisi akhir : 21 Desember 2012
MODIFICATION OF LBKP AND DEINKED PULP FIBER BY USING CARBOXYMETHYL CELLULOSE

\begin{abstract}
The strength properties of paper are strongly affected by fiber quality. The objective of this study was to assess the effect of modification fiber by carboxymethylation of leaf bleached kraft pulp (LBKP) and deinked pulp (DIP) by using carboxymethyl cellulose (CMC). Carboxymethylation was carried out by addition of various concentration of $\mathrm{CMC}$ and cationic agent of $\mathrm{CaCl}_{2}$. Handsheets with $70 \mathrm{gsm}$ were made from the stock, and the physical properties were tested as the tensile index, stretch, tensile energy absorption (TEA), tearing index, and bursting index as well as SEM analysis. The results showed that the highest increase of fiber strength of LBKP and DIP was achieved by addition of $1 \%$ CMC and $9.19 \% \mathrm{CaCl}_{2}$. For LBKP, the increasing of tensile index was $18.1 \%$, stretch $27 \%$, TEA 30.2\%, tear index $7,8 \%$ and burst index $16,7 \%$. Whereas for DIP, the increasing of tensile index reached $29.9 \%$, stretch $22.2 \%$, TEA $61.2 \%$, tear index $20.7 \%$ and burst index $63.1 \%$. From the results of SEM analysis showed that the addition of $\mathrm{CMC}$ and $\mathrm{CaCl}_{2}$ increased fiber bonding.
\end{abstract}

Keywords: CMC, LBKP, DIP

\begin{abstract}
ABSTRAK
Sifat kekuatan kertas sangat dipengaruhi oleh kualitas serat. Tujuan penelitian ini adalah untuk mengetahui pengaruh modifikasi serat kraft putih kayu daun (LBKP) dan serat hasil deinking (DIP) dengan karboksimetilasi menggunakan karboksimetil selulosa (CMC). Modifikasi secara karboksimetilasi dilakukan dengan variasi penambahan $\mathrm{CMC}$ dan sebagai cationic agent $\mathrm{CaCl}_{2}$. Lembaran dibuat dari stok dengan gramatur 70 gsm, kemudian dilakukan pengujian fisik dengan parameter indeks tarik, regang, TEA, indeks sobek dan indeks retak. Selain itu lembaran juga diuji morfologi dan SEM. Hasil penelitian menunjukan peningkatan kekuatan lembaran tertinggi dicapai oleh LBKP maupun DIP, pada kondisi penambahan $1 \% \mathrm{CMC}$ and $9.19 \% \mathrm{CaCl}_{2}$. Untuk LBKP peningkatan indeks tarik adalah $18,1 \%$, regang $27 \%$, TEA 30,2\%, indeks sobek 7,8 \% dan indeks retak 16,7\%. Sedangkan untuk DIP, peningkatan indeks tarik mencapai $29,9 \%$, regang $22,2 \%$, TEA $61,2 \%$, indeks sobek $20,7 \%$ dan indeks retak $63,1 \%$. Hasil analisa SEM menunjukan bahwa dengan penambahan $\mathrm{CMC}$ dan $\mathrm{CaCl}_{2}$, mengakibatkan terjadi peningkatan ikatan antar serat.
\end{abstract}

Kata kunci: CMC, LBKP, DIP

\section{PENDAHULUAN}

Kebutuhan kertas dewasa ini terus meningkat, seiring dengan peningkatan ekonomi dan daya beli masyarakat. Indonesia sebagai negara tropis memiliki sumber serat LBKP yang melimpah. Selain itu menurut Holik (2006) Indonesia juga merupakan negara terbesar ketiga, yang menggunakan serat daur ulang seperti DIP sebagai sumber bahan baku kertas. Akan tetapi hingga saat ini untuk meningkatkan kekuatan kertas yang dihasilkan, Indonesia masih mengimpor serat panjang yang berasal dari pulp kayu jarum seperti Needle Bleached Kraft 
Pulp (NBKP). Dengan demikian penelitian mengenai modifikasi serat LBKP dan DIP untuk meningkatkan kekuatan lembaran kertas, sangat diperlukan untuk mengurangi ketergantungan import Indonesia terhadapa NBKP.

Sifat fisik yang terdapat pada lembaran kertas merupakan hasil interaksi dari fleksibilitas, kekuatan ikatan dan kekuatan serat yang berada dalam lembaran tersebut. Pengujian sifat fisik kertas yang umum dilakukan adalah ketahanan tarik, ketahanan retak, ketahanan sobek,porositas dan kelicinan. Secara umum sifat fisik suatu lembaran kertas dipengaruhi oleh morfologi serat (panjang dan diameter serat), jumlah ikatan serat, kekuatan dari ikatan serat, gramatur atau berat serat dan kadar air. Interaksi antara serat dengan serat maupun serat dengan aditif merupakan faktor utama yang mempengaruhi sifat fisik suatu lembaran kertas. Selama ini untuk mendapatkan kekuatan melalui ikatan antar serat maupun ikatan serat-aditif diperoleh melalui proses refining bahan baku dan penambahan aditif wet-end

Muatan gugus hidroksil serat memegang peranan yang sangat penting pada sifat kertas, sama halnya dengan sifat serat dalam proses pembuatan kertas. Muatan serat akan berpengaruh terhadap swelling dan fleksibilitas serat atau mempengaruhi ikatan serat atau kekuatan ikatan spesifik.

Saat ini menurut Arndt dan Zelm (2008) cara umum yang digunakan untuk meningkatkan jumlah muatan gugus hidroksil serat adalah sulfonasi, oksidasi dan karboksimetilasi .

Karboksimetilasi merupakan suatu metode untuk meningkatkan gugus hidroksil dan swelling pada serat, yang berdampak pada peningkatan kekuatan kertas. Proses karboksimetilasi serat menunjukan akan terjadinya peningkatan kekuatan ikatan spesifik antar serat, akan tetapi menurut Fors, C. (2000) proses ini memiliki kekurangan bahwa pada serat yang telah mengalami proses swelling akan cenderung lebih sulit untuk proses penghilangan air atau dewatering .

Penelitian sebelumnya telah dilakukan oleh Liimatainen dkk. (2009), Duker dan Lindström (2008), dan Blomstedt (2007), namun metode yang digunakan masih menggunakan sumber serat NBKP, dan dilakukan pada temperatur tinggi, hal ini akan menghambat penerapan pada skala industri karena kenaikan temperatur akan meningkatkan biaya produksi kertas. Sehingga dikembangkan metode karboksimetilasi menggunakan temperatur lebih rendah. Selain itu, pada penelitian sebelumnya pengaruh CMC terhadap peningkatan kekuatan kertas belum terlalu jelas digambarkan secara eksplisit, sehingga dilakukan analisis SEM untuk mengetahui pengaruh penambahan CMC terhadap perubahan struktur serat.

Tujuan penelitian adalah mengetahui pengaruh karboksimetilasi permukaan serat LBKP dan DIP menggunakan CMC dan $\mathrm{CaCl}_{2}$ terhadap kekuatan lembaran kertas yang dihasilkan.

\section{BAHAN DAN METODE}

\section{Bahan}

Bahan baku yang digunakan terdiri dari LBKP, kertas koran bekas (ONP) import. Untuk proses deinking digunakan $\mathrm{NaOH}$, natrium silikat, $\mathrm{H}_{2} \mathrm{O}_{2}$, dan EDTA, sedangkan untuk proses karboksimetilasi digunakan $\mathrm{CMC}$ dan $\mathrm{CaCl}_{2}$.

\section{Metode}

\section{Pembuatan Lembaran LBKP}

Pulp LBKP digiling hingga mencapai derajat giling $300 \mathrm{~mL}$ Canadian Standard Freeness (CSF) pada konsistensi 1,5\%, kemudian ditambahkan $\mathrm{CaCl}_{2}$ sesuai dengan Tabel 1, stok pulp dipanaskan hingga mencapai temperatur $50-55^{\circ} \mathrm{C}$ kemudian ditambahkan CMC dengan derajat subtitusi (DS) 0,52 sesuai dengan variasi yang tertera pada Tabel 1 , diaduk hingga homogen dan dibuat lembaran tangan dengan gramatur $70 \mathrm{~g} / \mathrm{m}^{2}$.

Tabel 1.Variasi Komposisi Lembaran Pulp LBKP

\begin{tabular}{cccc}
\hline No & Kode & $\mathrm{CaCl}_{2}(\%)$ & $\mathrm{CMC}(\%)$ \\
\hline 1 & $\mathrm{~S}-1$ & - & - \\
2 & $\mathrm{~S}-2$ & 0,496 & - \\
3 & $\mathrm{~S}-3$ & 0,496 & 1 \\
4 & $\mathrm{~S}-4$ & 9,190 & 1 \\
\hline
\end{tabular}

\section{Pembuatan Lembaran DIP}

Sumber DIP yang digunakan pada penelitian ini berasal dari kertas koran bekas impor dengan kondisi deinking sebagai berikut: $1 \mathrm{~kg}$ serat kering oven ditambahkan $\mathrm{NaOH} 1 \%$, natrium silikat 2,5\%, $\mathrm{H}_{2} \mathrm{O}_{2} 1 \%$, dan EDTA 0,5\%. Kemudian 
ditambahkan air pada hidropulper sebanyak $23.841 \mathrm{~mL}$ dan dipanaskan pada temperatur $50^{\circ} \mathrm{C}$. Setelah itu dilakukan proses flotasi selama 15 menit, dan dicuci sampai netral.

DIP diencerkan hingga konsistensi 1,5\%, kemudian ditambahkan $\mathrm{CaCl}_{2}$ dengan variasi penambahan sesuai dengan Tabel 2, stock dipanaskan hingga mencapai temperatur $50-55^{\circ} \mathrm{C}$, lalu ditambahkan $\mathrm{CMC}(\mathrm{DS}=0,52)$ dengan variasi konsentrasi sesuai Tabel 2. Kemudian dibuat lembaran tangan dengan gramatur $70 \mathrm{~g} / \mathrm{m}^{2}$.

Tabel 2. Komposisi Lembaran Deinked Pulp (DIP)

\begin{tabular}{cccc}
\hline No & Kode & $\mathrm{CaCl}_{2}(\%)$ & $\mathrm{CMC}(\%)$ \\
\hline 1 & $\mathrm{~S}-5$ & - & - \\
2 & $\mathrm{~S}-6$ & 0,496 & - \\
3 & $\mathrm{~S}-7$ & 0,496 & 1 \\
4 & $\mathrm{~S}-8$ & 9,19 & 1 \\
\hline
\end{tabular}

\section{Analisis Sifat Fisik Lembaran}

Lembaran uji dikondisikan sesuai dengan standar SNI tentang kondisi ruang penyimpanan contoh pada temperatur $23 \pm 1^{\circ} \mathrm{C}$ dan kelembaban udara $(\mathrm{RH}) 50 \pm 2 \%$. Kemudian dilakukan pengujian sifat fisik dengan parameter indeks tarik, regang dan TEA menggunakan alat uji tarik merk TMI, model 84-21-01-00002. Ketahanan sobek menggunakan alat uji sobek Elmendorf merk TMI , model 83-11-01-0002. Kemudian ketahanan retak menggunakan alat uji retak L \& $\mathrm{W}$, tipe 11-2. Metode pengujian dilakukan seperti pada Tabel 3. Untuk mengetahui pengaruh CMC dan $\mathrm{CaCl}_{2}$ terhadap fines dilakukan pengujian morfologis menggunakan fiber tester L\&W.

\section{Sifat Fisik Lembaran}

Pada penelitian ini kondisi modifikasi serat dengan CMC dilakukan pada temperatur $50^{\circ}-55^{\circ} \mathrm{C}$, hal ini berbeda dengan penelitian sebelumnya oleh Blomstedt (2007) dan Laine dkk. ( 2003) dimana proses modifikasi serat dilakukan pada temperatur $120^{\circ} \mathrm{C}$ dan temperatur $60^{\circ} \mathrm{C}$. Kondisi ini dilakukan karena pada industri kertas penggunaan temperatur erat kaitannya dengan peningkatan konsumsi kukus (steam) yang pada akhirnya akan meningkatkan biaya produksi. Hasil pengujian sifat fisik, untuk pulp LBKP dan DIP terlihat pada Tabel 4.

Tabel 3. Parameter Uji Lembaran

\begin{tabular}{rll}
\hline No & \multicolumn{1}{c}{ Parameter } & \multicolumn{1}{c}{ Metode Uji } \\
\hline 1 & Ketahanan sobek & SNI 0436:2009, Kertas - Cara uji ketahanan sobek - (Metode Elmendorf) \\
2 & Ketahanan tarik, & SNI ISO 1924-2:2010, Kertas dan karton - Cara uji sifat tarik - Bagian 2:Metode \\
& regang, dan TEA & kecepatan elongasi tetap \\
3 & Ketahanan retak & SNI ISO 2758:2011, Kertas - Cara uji ketahanan retak . \\
4 & Klasifikasi dan & ISO 16065-2:2007, Pulps - Determination of fibre length by automated optical \\
& morfologi & analysis - Part 2: Unpolarized light method \\
\hline
\end{tabular}

Tabel 4. Data Hasil Pengujian Sifat Fisik Lembaran

\begin{tabular}{clcccccc}
\hline $\begin{array}{c}\text { Jenis } \\
\text { pulp }\end{array}$ & Kode & $\begin{array}{c}\text { Gramatur } \\
\left(\mathrm{g} / \mathrm{m}^{2}\right)\end{array}$ & $\begin{array}{c}\text { Indeks tarik } \\
(\mathrm{Nm} / \mathrm{g})\end{array}$ & $\begin{array}{c}\text { Regang } \\
(\%)\end{array}$ & $\begin{array}{c}\text { TEA } \\
\left(\mathrm{kgfm} / \mathrm{m}^{2}\right)\end{array}$ & $\begin{array}{c}\text { Indeks sobek } \\
\left(\mathrm{mNm}^{2} / \mathrm{g}\right)\end{array}$ & $\begin{array}{c}\text { Indeks retak } \\
(\mathrm{kN} / \mathrm{g})\end{array}$ \\
\hline \multirow{4}{*}{ LBKP } & S-1 & 84,3 & 39,56 & 2,00 & 4,21 & 7,90 & 2,21 \\
& S-2 & 78,4 & 42,63 & 2,25 & 4,84 & 8,07 & 2,39 \\
& S-3 & 76,2 & 40,98 & 2,43 & 4,96 & 8,35 & 2,49 \\
& S-4 & 72,8 & 46,73 & 2,54 & 5,48 & 8,52 & 2,58 \\
\hline \multirow{4}{*}{ DIP } & S-5 & 66,0 & 22,63 & 2,03 & 2,09 & 7,83 & 1,11 \\
& S-6 & 75,4 & 23,41 & 2,05 & 2,08 & 8,57 & 1,62 \\
& S-7 & 71,2 & 28,49 & 2,40 & 3,21 & 8,59 & 1,77 \\
& S-8 & 74,8 & 29,39 & 2,48 & 3,37 & 9,45 & 1,81 \\
\hline
\end{tabular}




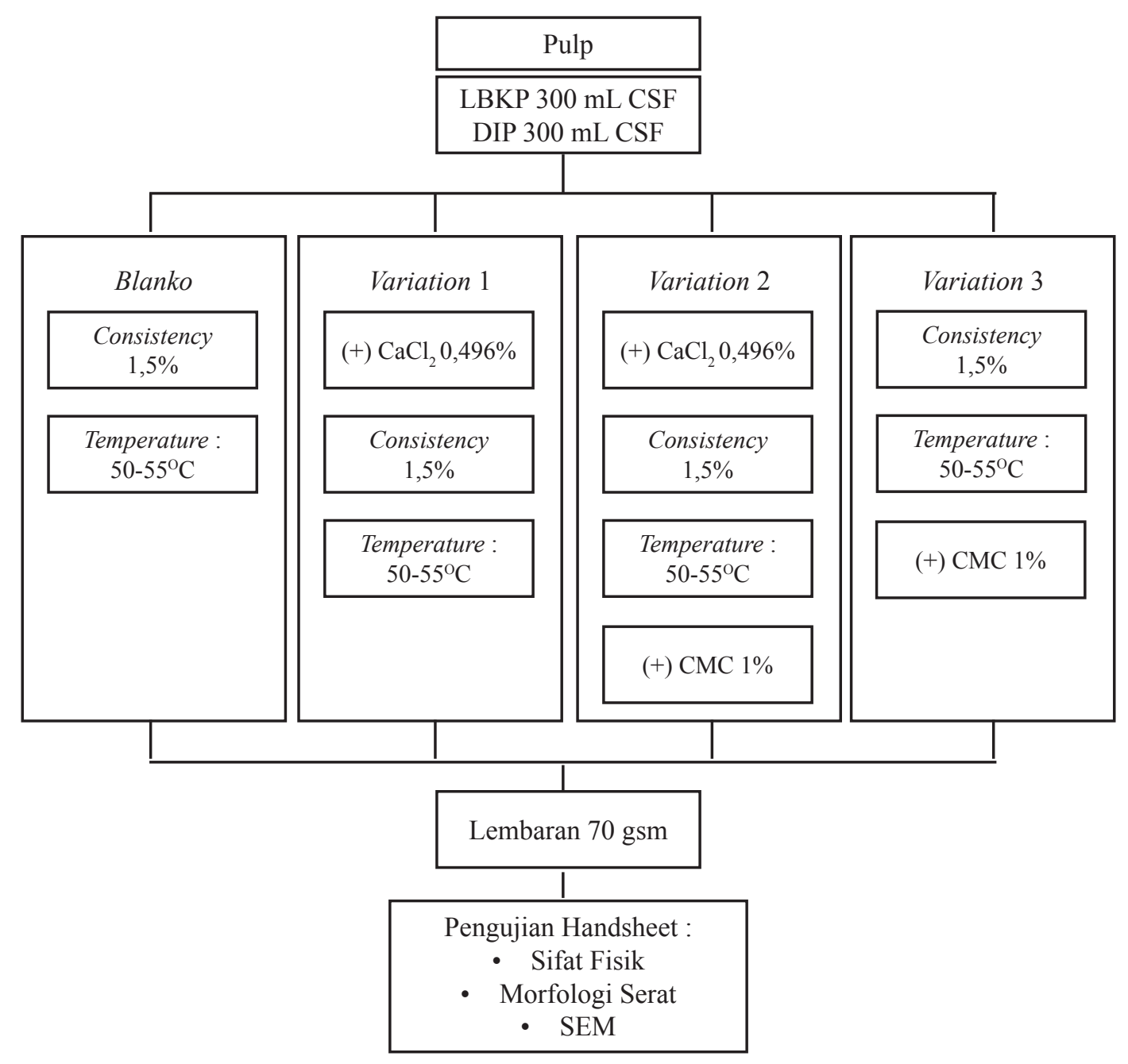

Gambar 1. Diagram Alir Percobaan

Pada S-2 (LBKP, $\mathrm{CaCl}_{2}$ 0,496\%) dan S-6 (DIP, $\left.\mathrm{CaCl}_{2}, 0,496 \%\right)$ terjadi peningkatan kekuatan dibandingkan dengan blanko (S-1 dan S-5) kemungkinan dikarenakan $\mathrm{CaCl}_{2}$ yang bertindak sebagai cationic agent yang akan menurunkan muatan zeta potensial stok, sehingga akan mengurangi gaya tolak-menolak antar serat yang pada akhirnya dapat meningkatkan kekuatan lembaran. Hal ini sesuai dengan hasil penelitian sebelumnya (Liimatainen et al. 2009) yang menunjukkan bahwa pada proses karboksimetilasi menggunakan $\mathrm{CMC}(\mathrm{DS}=0,52)$ keberadaan $\mathrm{CaCl}_{2}$ sebagai elektrolit dapat meningkatkan penyerapan CMC terhadap permukaan serat, yang diakibatkan karena pengaruh elektrolit yang akan mengurangi gaya tolak-menolak anionik antara serat - CMC

Indeks tarik merupakan nilai katahanan tarik dibagi dengan gramatur, sedangkan ketahanan tarik adalah gaya tarik maksimum per satuan lebar yang menyebabkan kertas atau karton akan bertahan sesaat sebelum putus dibawah kondisi yang dijelaskan dalam metoda uji standar (SNI ISO 1924-2.2010) Ketahanan tarik dipengaruhi oleh beberapa faktor seperti panjang serat, ikatan antar serat, tingkat penggilingan, jumlah dan jenis aditif, tahap pengempaan dan gramatur atau berat dasar lembaran. Panjang serat dapat mempengaruhi nilai ketahanan tarik, tetapi jumlah dan ikatan antar serat merupakan parameter yang penting untuk mengoptimasi sifat kekuatan tarik (Holik, 2006).

Gambar 2 menunjukan bahwa terjadi peningkatan nilai indeks tarik dengan penambahan $\mathrm{CaCl}_{2}$ dan $\mathrm{CMC}$, baik untuk lembaran yang berasal dari pulp LBKP maupun dari DIP . Hal ini membuktikan bahwa penambahan $\mathrm{CMC}$ dapat meningkatkan ikatan serat sehingga dapat menaikkan nilai indeks tarik walaupun tidak dilakukan penambahan serat panjang. Hal ini sesuai dengan penelitian Duker E. dan LindstrÖm, T. (2008) yang menyatakan bahwa penambahan CMC dapat meningkatkan ketahanan tarik 


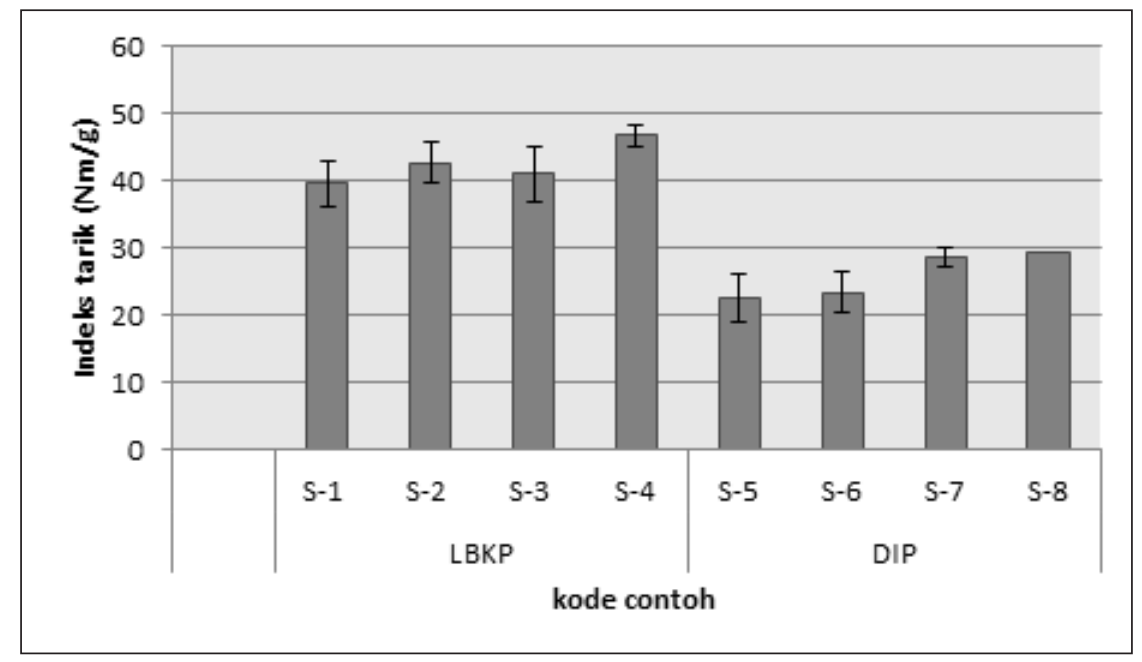

Gambar 2. Grafik Indeks Tarik Lembaran LBKP dan DIP pada Berbagai Variasi Penambahan $\mathrm{CaCl}_{2}$ dan CMC

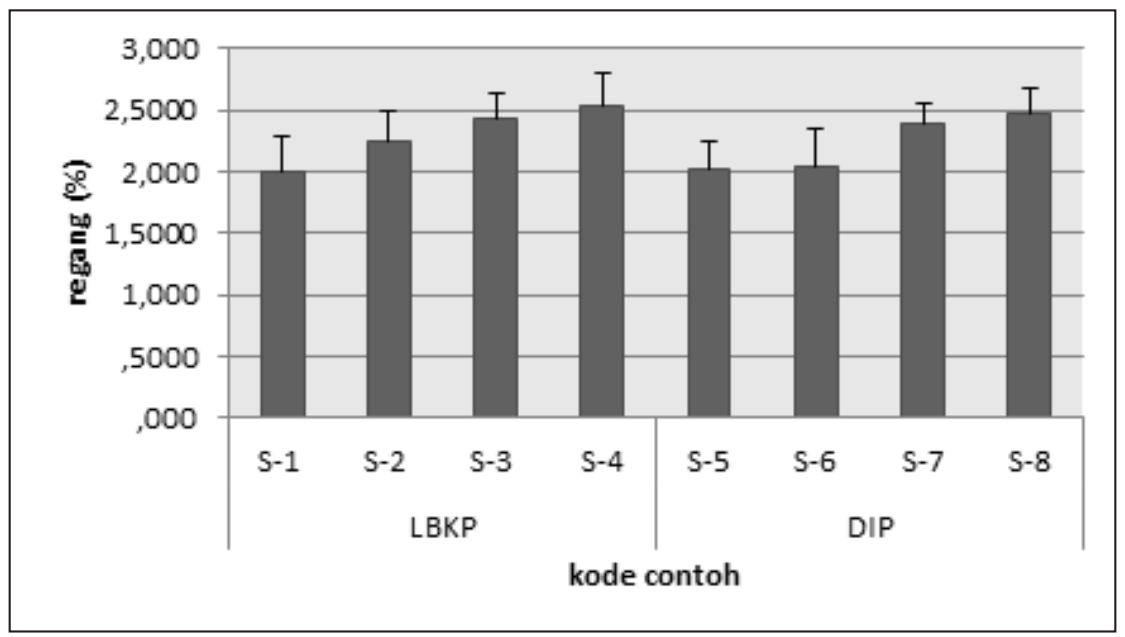

Gambar 3 . Grafik Daya Regang Lembaran LBKP dan DIP pada Berbagai Variasi Penambahan $\mathrm{CaCl}_{2}$ dan $\mathrm{CMC}$

lembaran dengan cara meningkatkan formasi dan jumlah ikatan antar serat.

Menurut Holik, (2006). hal yang mempengaruhi regang suatu lembaran adalah panjang serat, bahan pengisi, derajat giling, dan elastisitas atau fleksibilitas serat. Berdasarkan penelitian sebelumnya (Blomstedt, Minna. 2007 dan Blomstedt, Minna.et all. 2007) menyatakan bahwa penambahan CMC akan meningkatkan plastisitas dan fleksibilitas serat, dan meningkatkan kemampuan serat tersebut untuk berikatan pada saat pembentukan lembaran, sehingga dapat meningkatkan kekuatan kertas. Dari gambar 3 diketahui nilai regang yang paling tinggi didapat oleh kode S-4 untuk lembaran yang berasal dari LBKP, dan S-8 yang berasal dari DIP. Hal ini menunjukan bahwa peningkatan konsentrasi $\mathrm{CaCl}_{2}$ dapat meningkatkan retensi CMC terhadap serat, sehingga kemampuan serat untuk berikatan lebih tinggi yang pada akhirnya dapat meningkatkan nilai regang lembaran.

Nilai TEA merupakan gabungan dari nilai tarik dan regang lembaran kertas. Gambar 4 menunjukan dengan penambahan $\mathrm{CaCl}_{2}$ dan CMC dapat meningkatkan nilai TEA, karena dengan penambahan kedua zat tersebut maka nilai regang lembaran juga akan meningkat . Nilai TEA yang paling tinggi diperoleh oleh S-4 untuk lembaran LBKP dan S-8 untuk lembaran DIP. Nilai ketahanan sobek dipengaruhi oleh panjang serat dan banyaknya jumlah ikatan serat yang terlibat pada saat penyobekan. 


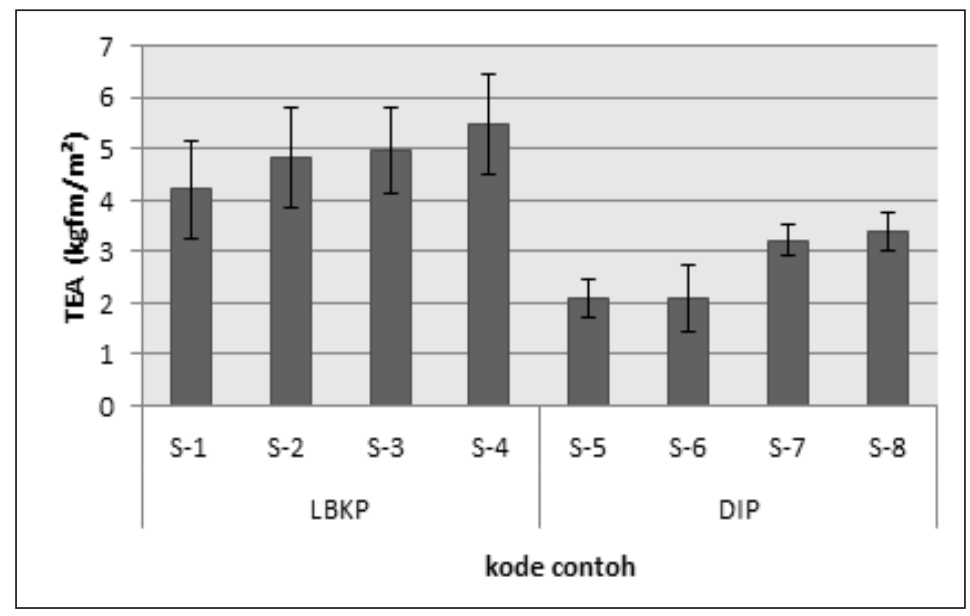

Gambar 4. Grafik TEA Lembaran LBKP dan DIP pada Berbagai Variasi Penambahan $\mathrm{CaCl}_{2}$ dan $\mathrm{CMC}$

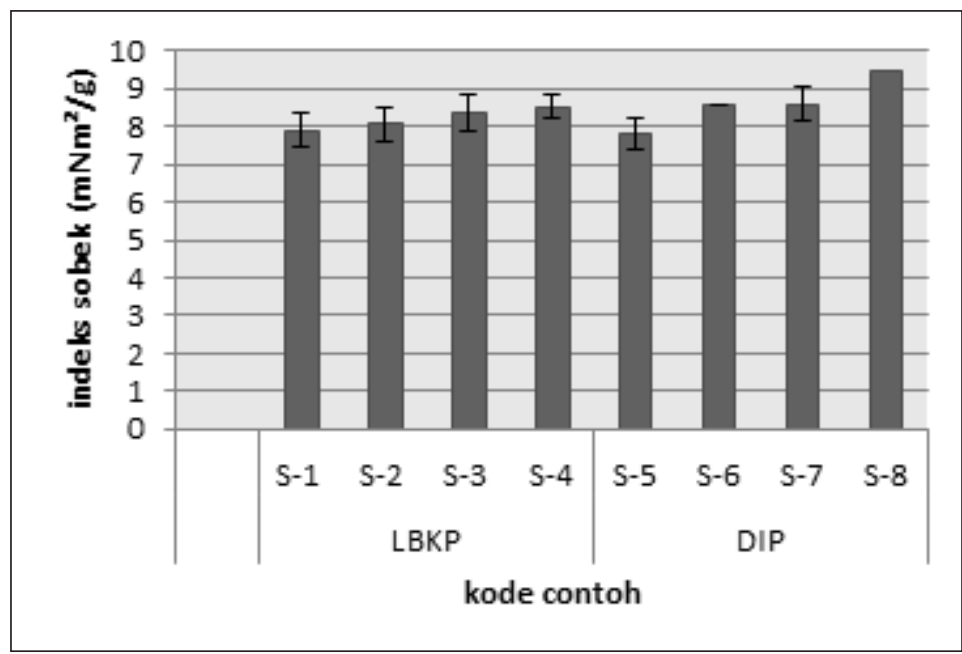

Gambar 5. Grafik Indeks Sobek Lembaran LBKP dan DIP pada Berbagai Variasi Penambahan $\mathrm{CaCl}_{2}$ dan $\mathrm{CMC}$

Gambar 5 menunjukan bahwa dengan penambahan $\mathrm{CaCl}_{2}$ dan $\mathrm{CMC}$ cenderung meningkatkan nilai ketahanan sobek, hal ini diduga karena dengan penambahan CMC dan $\mathrm{CaCl}_{2}$ maka akan terbentuk ikatan antar serat yang lebih banyak sehingga dapat meningkatkan nilai ketahanan sobek lembaran.

Nilai ketahanan sobek tertinggi didapat pada contoh yang mengalami penambahan $\mathrm{CaCl}_{2}$ 9,19 $\%$ dan CMC $1 \%$ baik itu pada lembaran yang berasal dari pulp LBKP maupun DIP.Untuk lembaran pulp LBKP kenaikan tertinggi mencapai $7,8 \%$ dibandingkan nilai ketahanan sobek blanko. Sedangkan untuk lembaran yang berasal dari pulp DIP kenaikan tertinggi mencapai 20,6\%. Seperti parameter kekuatan fisik lembaran yang lain, hasil pengujian indeks retak pada Gambar 6 menunjukan adanya peningkatan ketahanan retak setelah penambahan $\mathrm{CMC}$ dan $\mathrm{CaCl}_{2}$. Untuk lembaran pulp LBKP kenaikan tertinggi diperoleh oleh contoh kode S-4 dengan kenaikan sebesar $16,7 \%$. Sedangkan untuk lembaran yang berasal dari DIP, kenaikan terbesar didapat oleh kode S-8 dengan kenaikan sebesar 63,1\% dibandingkan dengan blanko (S-1 dan S-5).

Dari seluruh hasil penelitian terlihat bahwa kenaikan kekuatan lembaran tertinggi untuk seluruh parameter diperoleh dari lembaran yang berasal dari DIP, hal ini belum dapat dipastikan dengan jelas, tapi diperkirakan karena pada lembaran DIP telah mengalami penggilingan berulang kali, sehingga terjadi 


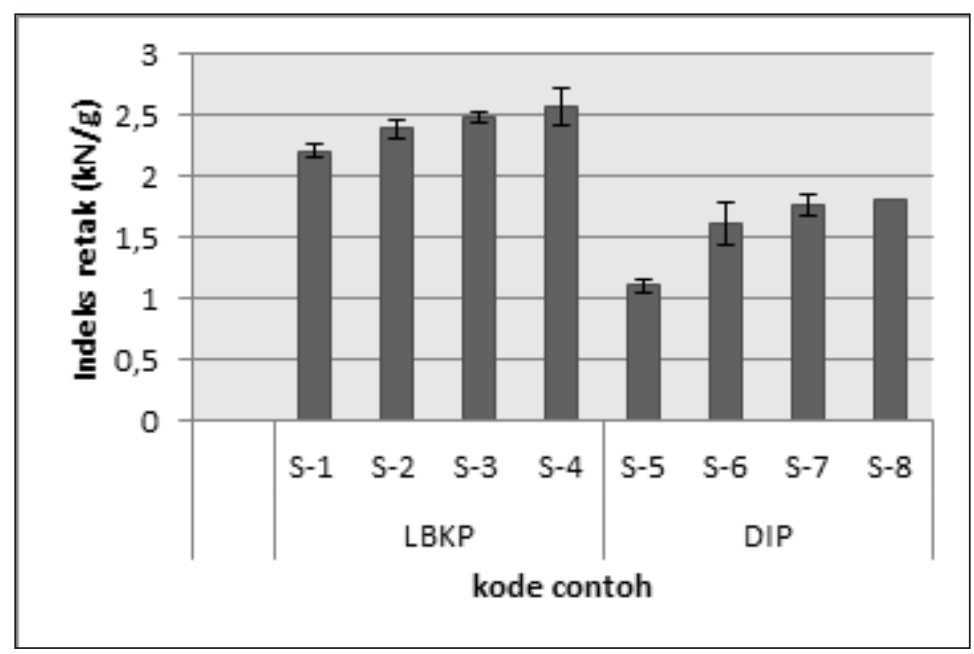

Gambar 6. Grafik Indeks Retak Lembaran LBKP dan DIP pada Berbagai Variasi Penambahan $\mathrm{CaCl}_{2}$ dan $\mathrm{CMC}$

Tabel 5. Hasil Uji Morfologi Serat

\begin{tabular}{ccccc}
\hline Jenis pulp & Kode & $\begin{array}{c}\text { Mean Length } \\
\text { mm }\end{array}$ & $\begin{array}{c}\text { Mean Width } \\
\text { mm }\end{array}$ & $\begin{array}{c}\text { Fines } \\
\%\end{array}$ \\
\hline \multirow{6}{*}{ LBKP } & S-1 & 0,839 & 22,6 & 11,5 \\
& S-2 & 0,805 & 22,4 & 11,1 \\
& S-3 & 0,801 & 22,4 & 11,0 \\
& S-4 & 0,810 & 22,5 & 10,5 \\
\hline \multirow{6}{*}{ DIP } & S-5 & 1,140 & 26,6 & 10,3 \\
& S-6 & 1,182 & 26,6 & 9,6 \\
& S-7 & 1,164 & 26,4 & 9,5 \\
& S-8 & 1,169 & 26,5 & 9,4 \\
\hline
\end{tabular}

penurunan kekuatan yang cukup besar, dengan proses karboksimetilasi dengan CMC ini, mengakibatkan peningkatan kekuatan yang lebih tinggi dibandingkan dengan lembaran yang berasal dari LBKP.

\section{Hasil Uji Morfologi Serat}

Fines berperan sebagai pengisi bagianbagian kosong diantara serat-serat dalam pembentukan lembaran. Dari Tabel 5 dapat dilihat bahwa dengan penambahan $\mathrm{CaCl}_{2}$ dan CMC mengakibatkan jumlah fines menurun baik untuk LBKP maupun DIP. Hal ini sesuai dengan penelitian sebelumnya Blomstedt, et all. (2007) yang diduga karena CMC menyebabkan fines terflokulasi sehingga menjadi fraksi serat yang lebih besar dan tidak terbaca sebagai fines.
Pada Gambar 7 dan Gambar 8 dapat terlihat suatu hubungan bahwa dengan penambahan CMC dan $\mathrm{CaCl}_{2}$ dapat meningkatkan sifat kekuatan lembaran tetapi hal ini juga menyebabkan berkurangnya jumlah fraksi fines, baik untuk serat LBKP maupun DIP.

Dari Gambar 9 dan Gambar 10 menunjukan bahwa penambahan $\mathrm{CaCl}_{2}$ dan $\mathrm{CMC}$ menyebabkan terurainya gumpalan mikrofibril yang mengakibatkan sejumlah besar air dapat terikat pada mikrofibril eksternal sehingga terjadi pengembangan serat atau swelling. Fenomena ini sesuai dengan penelitian Blomstedt, (2007), yang berdampak positif terhadap kekuatan kertas, karena dengan semakin banyak terbentuk mikrofibril diduga jumlah ikatan antar serat juga akan meningkat sehingga menaikkan sifat kekuatan lembaran. 


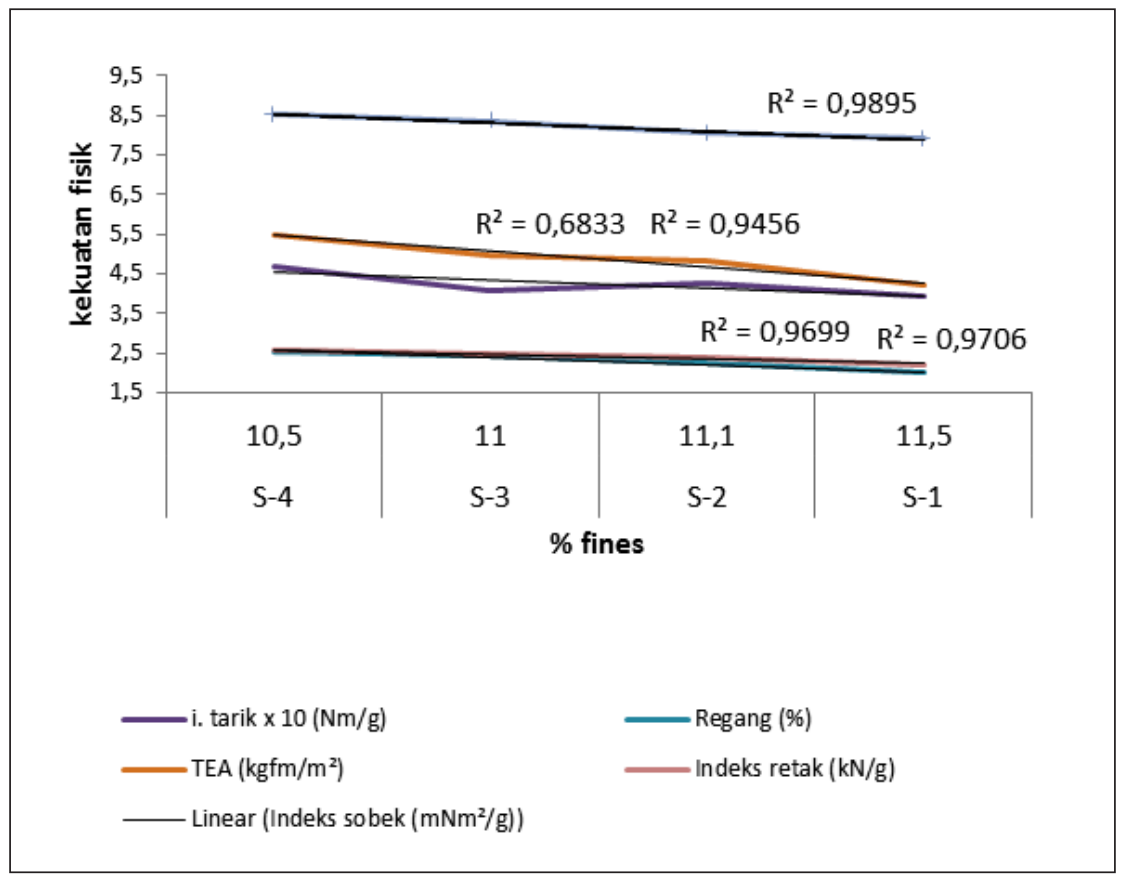

Gambar 7. Grafik Hubungan antara \% Fines dengan Kekuatan Fisik Lembaran LBKP

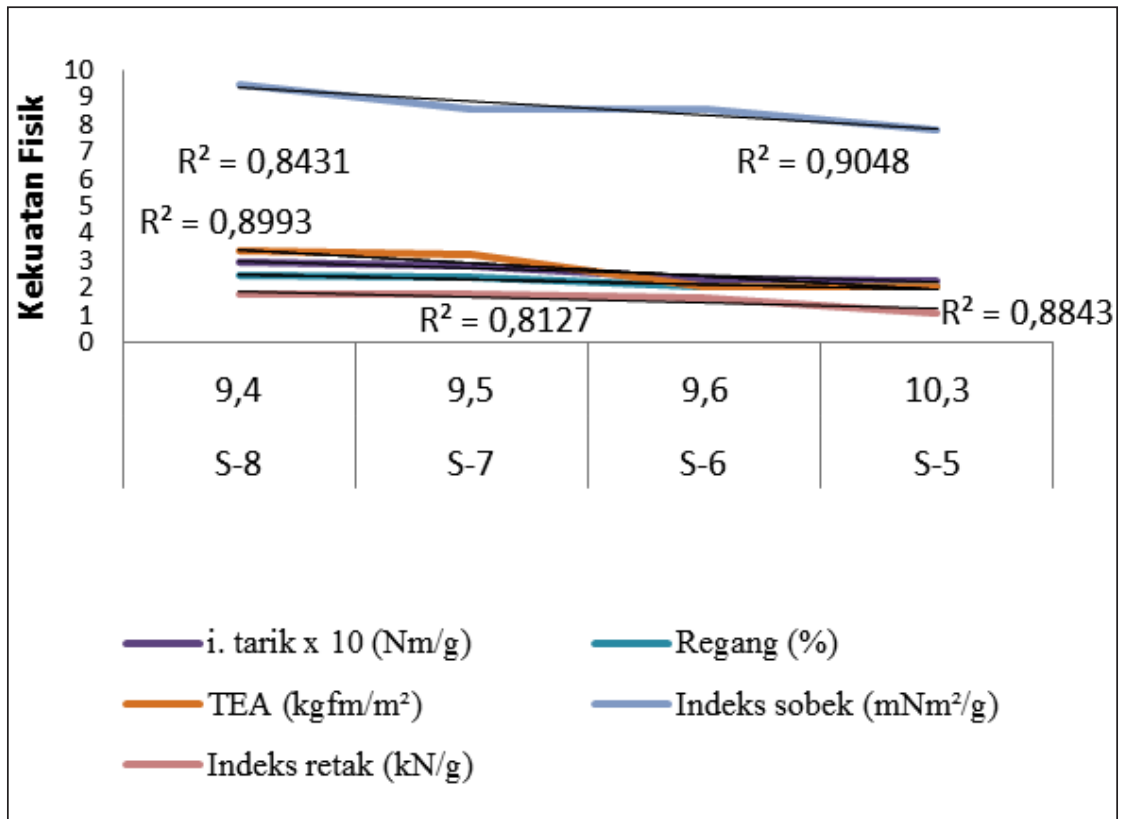

Gambar 8. Grafik Hubungan antara \% Fines dengan Kekuatan Fisik Lembaran DIP

Sedangkan hasil analisa SEM (Gambar 11) menunjukan bahwa modifikasi permukaan serat dengan penambahan $\mathrm{CaCl}_{2}$ dan $\mathrm{CMC}$ akan meningkatkan jumlah ikatan antar serat. Hal ini diduga diakibatkan karena fiber swelling yang dapat meningkatkan pembentukan mikrofibril dan ikatan antar serat. Proses modifikasi secara karboksimetilasi dengan penambahan $\mathrm{CaCl}_{2}$ dan CMC terhadap serat LBKP maupun DIP dapat meningkatkan nilai indeks tarik, regang, TEA, indeks sobek dan indeks retak lembaran. Berdasarkan hasil analisa mikroskop dan SEM, penambahan $\mathrm{CaCl}_{2}$ dan $\mathrm{CMC}$ berakibat terjadinya peningkatan jumlah ikatan antar serat. Dari hasil penelitian yang telah dilakukan, diketahui bahwa peningkatan kekuatan pada pulp DIP lebih tinggi dibandingkan proses karboksimetilasi pada serat primer LBKP. 


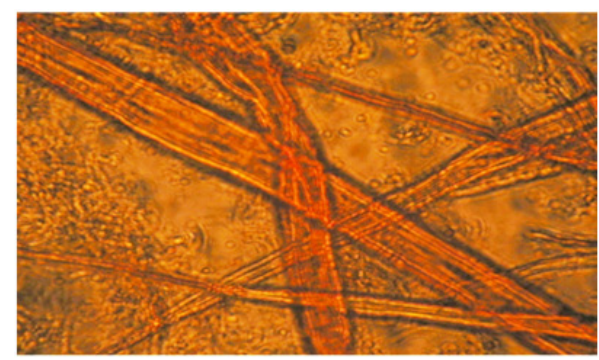

a) S-1 (LBKP Blanko) Serat Belum Swelling

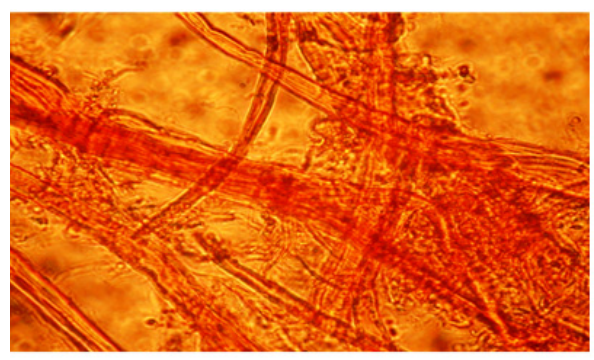

b) S-4 (LBKP, $\mathrm{CaCl}_{2}$ 9,19\%, CMC 1\%) Serat Setelah Swelling

Gambar 9. Hasil Analisa Mikroskop Serat LBKP (a) Serat LBKP Blanko Sebelum Modifikasi (b) Serat LBKP Setelah Modifikasi dengan CMC pada Penambahan $\mathrm{CaCl}_{2}$ 9, $19 \%$ dan $\mathrm{CMC} 1 \%$

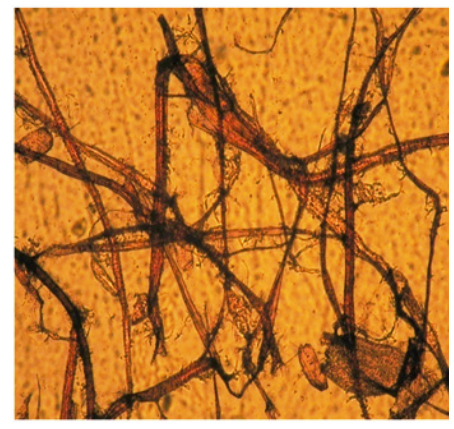

a) S-5 (DIP Blanko)

Serat Belum Swelling

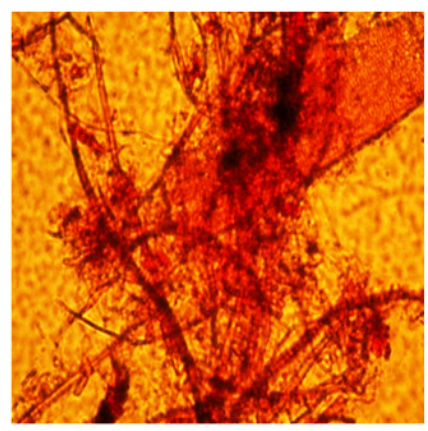

b) S-8 (DIP, $\mathrm{CaCl}_{2} 9,19 \%, \mathrm{CMC} 1 \%$ ) Serat Setelah Swelling

Gambar 10. Hasil Analisa Mikroskop Serat DIP (a) Serat DIP Blanko Sebelum Modifikasi (b) Serat DIP Setelah Modifikasi dengan CMC pada Penambahan $\mathrm{CaCl}_{2}$ 9,19\% dan CMC 1\%

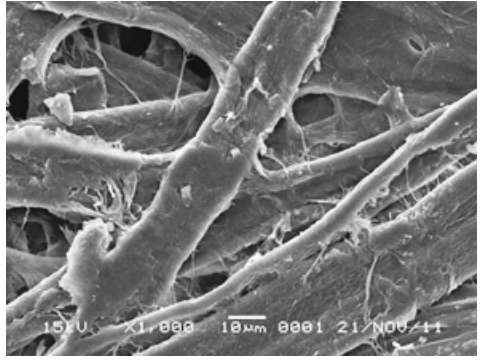

a. Serat LBKP Blanko (S-1)

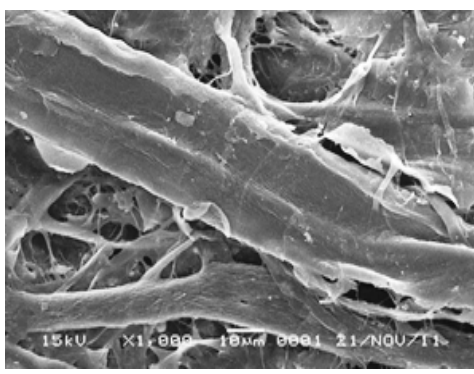

c. Serat DIP Blanko (S-5)

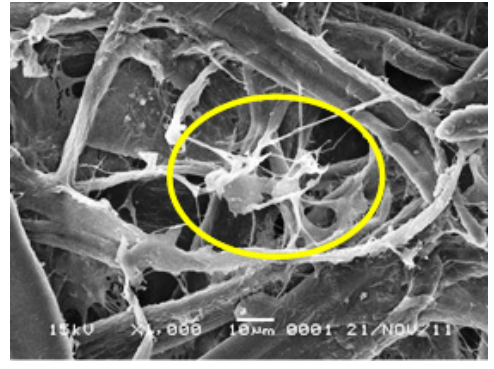

b. Serat LBKPS-4 $\left(\mathrm{CaCl}_{2}\right.$ 9,19\%, CMC 1\%)

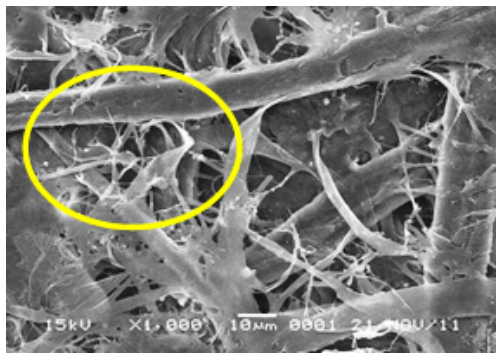

c. Serat DIP S-8 (CaCl2 9,19\%, CMC 1\%)

Gambar 11. Hasil SEM (a) Serat LBKP Blanko/S-1 sebelum Modifikasi (b) Serat LBKP Setelah Modifikasi / S-4 (c) Serat DIP/S-5 Blanko Sebelum Modifikasi (d) Serat DIP Setelah Modisikasi/S-8 


\section{UCAPAN TERIMA KASIH}

Pada kesempatan ini penulis mengucapkan terima kasih sebanyak-banyaknya pada teknisi Litkayasa Dadang SA., Maman S., Cucu, Enung FM., yang telah membantu dalam penelitian ini.

\section{DAFTAR PUSTAKA}

Arndt, T., Zelm, R. 2008. New nanotechnologyproduced fibre compounds in papermaking applications-review and first own experiences. Das Papier 9,59-63.

Saito, T. and Isogai, A. 2005. A novel method to improve wet strength of paper. Tappi J. 4(3): 3-8.

Blomstedt, M. 2007. Modification of Cellulosic Fibers by Carboxymethyl Cellulose - Effects on Fiber and Sheet Properties. Laboratory Of Forest Products Chemistry, Reports. Helsinki. Espoo

Blomstedt, M., Mitikka-Eklund, M., Vuorinen, T., 2007. Simplified modification of bleached softwood pulp with carboxymethyl cellulose. Appita. 60 (4): 309-314
Duker E dan Lindström, T. 2008. On the Mechanism Behind the ability of CMC to enhance Paper Strength. Nordic Pulp and Paper Research journal Vol. 23 no.1.hal. 5764

Fors, C. 2000. The effect of fibre charge on web consolidation in papermaking. Licentiate thesis, Royal Institute of Technology, Department of Pulp and Paper Chemistry and Technology, Stockholm, SwedenHolik, H . 2006. Handbook of Paper and Board. Weinheim: Wiley VCH Verlag GmbH \& Co. KGaA.

Laine, J., Lindstrom, T., Bremberg, C., GladNordmark, G. 2003. Studies on topochemical modification of cellulosic fibres part 4 . Toposelectivity of carboxymethylation and its effects on the swelling of fibres. Nordic Pulp and Paper Research journal Vol. 18 no.3: $316-324$

Liimatainen, H., Haapala, A., Niinimäki, J., Haavisto, S., 2009. Adsorbed and Dissolves CMC on Fibre Suspension Dispersing, Dewaterability, and Fines Retention. Bioresources 4 (1): 321-340 